University at Albany, State University of New York

Scholars Archive

$3-24-2014$

\title{
The Wax and the Mechanical Mind: Reexamining Hobbes's Objections to Descartes's Meditations
}

Marcus P. Adams

University at Albany, State University of New York, madams2@albany.edu

Follow this and additional works at: https://scholarsarchive.library.albany.edu/cas_philosophy_scholar

Part of the Philosophy Commons

\section{Recommended Citation}

Adams, Marcus P., "The Wax and the Mechanical Mind: Reexamining Hobbes's Objections to Descartes's Meditations" (2014). Philosophy Faculty Scholarship. 20.

https://scholarsarchive.library.albany.edu/cas_philosophy_scholar/20

This Article is brought to you for free and open access by the Philosophy at Scholars Archive. It has been accepted for inclusion in Philosophy Faculty Scholarship by an authorized administrator of Scholars Archive. For more information, please contact scholarsarchive@albany.edu. 
This is an Author's Original Manuscript of an article whose final and definitive form, the Version of Record, has been published in the British Journal for the History of Philosophy online on 24 Mar 2014, copyright Taylor \& Francis, available online at:

http://www.tandfonline.com/10.1080/09608788.2014.893226

\title{
The Wax and the Mechanical Mind: Reexamining Hobbes's Objections to Descartes's Meditations ${ }^{1}$
}

\author{
Marcus P. Adams \\ University of Pittsburgh \\ Department of History \& Philosophy of Science
}

\section{Introduction}

Hobbes's Objections to the Meditations on First Philosophy have disappointed many, including Descartes himself. Hobbes appears uncharitable or even incoherent at various points, and Descartes's Replies to him are curt and at times dismissive. For instance, in his Fourth Objection, Hobbes protests that "M. Descartes has not explained how they [imagining and conceiving] differ" (AT VII.178; CSM II.125). ${ }^{2}$ In this objection, it seems that Hobbes not only ignores the term Descartes uses in the Meditations-Hobbes misquotes the text, using conceive (concipere) rather than perceive (percipere)-but also overlooks Descartes's distinction in the Second Meditation between what the imagination reveals about the wax and what can be "perceived by the mind alone" (AT VII.31; CSM II.21). It is no surprise that Descartes replies with such a dismissive tone.

In this paper, I argue that understanding Hobbes's Objections within the context of his views in the late 1630 s and early 1640 s makes it clear that his criticisms are not only coherent, but in fact reflect

\footnotetext{
${ }^{1}$ I wish to thank Zvi Biener, Mary Domski, Daniel Garber, Geoffrey Gorham, Peter Machamer, Joseph Milburn, and Kathryn Tabb for helpful comments on an earlier version of this paper. I also thank the participants of the Hobbes and Spinoza Workshop at the Center for Philosophy of Science at the University of Pittsburgh in October 2013 for their feedback. This research was supported by a Fellowship from the Mellon Foundation and the American Council of Learned Societies.

2 I cite Descartes (1964-) as AT, Descartes (1985) as CSM, Descartes (1991) as CSMK, Hobbes (2005) as EW, Hobbes (1839-45) as OL, and Hobbes (1928) as EL, followed by chapter and article.
} 
a radical rejection of the Cartesian intellect in order to provide an epistemology amenable to mechanical philosophy. To make this argument, I examine Hobbes's Elements of Law (c. 1640) and Anti-White (1642-43), manuscript notes for De corpore by Hobbes, Robert Payne, and Charles Cavendish ${ }^{3}$ from the late 1630 s to the early $1640 \mathrm{~s},{ }^{4}$ and the culmination of those notes in De corpore (1655) itself. I do not wish to absolve Hobbes from the sin of unclear exposition. Rather, I argue that Hobbes's broader work provides the complete mechanism for scientific knowledge, and that his underdeveloped claims in the Fourth Objection are best understood as a brief summary of that mechanism. I have structured this paper around the mechanism found in his broader work, outlined below to show the connections between stages:

\section{Hobbes's Mechanism for Scientific Knowledge}

1. The motions from which scientific knowledge originates: Motions are "produced" by external bodies and are then "propagated" through various media to the human body;

2. The formation of conceptions by motions in the human body: The motions create images (conceptions) when they continue into the human body and "rebound" outward from the brain;

3. The cognitive activity of analyzing: The human cognitive power turns its attention toward the conceptions and "analyzes" or "resolves" them, from particular to general and from complex to simple; ${ }^{5}$

4. The knowledge (cognitio) of simplest conceptions: The human cognitive power "apprehends" the simplest conceptions reached after analysis; and

5. The cognitive activity of synthesizing ending in scientific knowledge: The human cognitive power "compounds" or "composes" these simplest conceptions back together in a synthesis to rebuild complex conceptions.

\footnotetext{
${ }^{3}$ Ms. 5297 (National Library of Wales), Chatsworth ms. A10, and Harleian ms. 6083, respectively. Jacquot and Jones (Hobbes 1973) transcribe ms. 5297. I thank His Grace the Duke of Devonshire, the Trustees of the Chatsworth Settlement, and Andrew Peppit and James Towe, the archivists at Chatsworth, for allowing me to examine ms. A10 during my visit to the archives in 2011. Harleian ms. 6083 has been digitized by the British Library and is available at http://www.bl.uk/manuscripts/FullDisplay.aspx?ref=Harley_MS_6083.

${ }^{4}$ Much scholarship has been concerned with Hobbes's intellectual development during this period. For example, Duncan (2005) argues that Hobbes was not a materialist in the 1640s, Shapiro (1973) highlights Hobbes's changing views of the propagation of light in media, and there have been extended debates about the authorship of the socalled "Short Tract" and what could be inferred from it about Hobbes's early thought (see, e.g., Tuck 1988; Raylor 2001; and Zagorin 1993). I show that Hobbes's mechanical account of mind and his epistemology remained consistent from the 1630s and 1640 s until its completion in De corpore.

${ }^{5}$ The nature of analysis for Hobbes will be discussed in greater detail below.
} 
Although commentators have been interested in Hobbes's Objections, ${ }^{6}$ many view them as uncharitable or incoherent. For example, Tom Sorrell argues that Hobbes "seems to miss [Descartes's] point" in his Fourth Objection, claiming that "Hobbes does not see that it is the objectivity of conception rather than the process of conception with which Descartes is concerned." ${ }^{7}$ However, as I show, the objectivity of conception and the process of conception are necessarily simultaneous projects for Hobbes. He cannot address one without the other because, unlike Descartes, who posited a faculty of the intellect in the Meditations, Hobbes did not believe that such a faculty was consistent with mechanical philosophy. Conjecturing the existence of the intellect and describing its activity as "perceiving" the nature of the wax was, to Hobbes, positing an uninformative black box. ${ }^{8}$

My argument proceeds in three stages. First, I discuss Descartes's Second Meditation on the nature of the wax alongside Hobbes's Fourth Objection. I show that the crux of their disagreement is not about language, as might appear to be the case, but rather the distinction between imagining and conceiving spurred by Hobbes's rejection of a faculty psychology. Next, I examine what I call Hobbes's mechanical epistemology, in which we have scientific knowledge (scientia) without an intellect. I argue that Hobbes's work outside of the Objections replaces the intellect with conceiving, which is precisely the mechanical activity of the mind that figures prominently in his Fourth Objection, and that Hobbes's mechanical epistemology and philosophical psychology should be understood as providing a mechanism to make scientific knowledge mechanically intelligible. ${ }^{9}$ Finally, I revisit the Fourth Objection and argue

\footnotetext{
${ }^{6}$ For example, Alanen (2003, 119); Lennon (1974); Mori (2012).

${ }^{7}$ Sorell $(1995,88)$. For similar criticisms, see Costa $(1983,544)$. Curley defends Hobbes's understanding of the Second Meditation but finds Hobbes "at his most dogmatic" in a later Objection (1995, 104; see Duncan 2005, 446-447, for criticism of this latter point).

${ }^{8}$ Clarke (2003, 9; cf. 35ff) views Descartes's appeal to mental faculties in the Meditations, compared with his natural-philosophical work on the human body before the Meditations, as a non-explanatory stopping point that should be seen as a "provisional halt" of explanation, not as some in-principle limit.

${ }^{9}$ Rather than seeing Hobbes as having supplanted the active intellect with language (cf. Leijenhorst 2001, 94), on my account conceiving replaces the active intellect. For more discussion on language replacing the intellect, see Leijenhorst $(2007,97)$ and Pettit $(2008,29)$.
} 
that Hobbes's work on conceiving in the late 1630s and early 1640 s expands upon the mechanism briefly summarized in the Fourth Objection.

\section{The Wax in the Second Meditation and Hobbes's Objection}

\section{1 "Tak[ing] off the clothes, as it were": Descartes's Method and the Wax}

The wax example provides the final step toward the Second Meditation's goal of clarifying the nature of the mind (Wagner 1995); it demonstrates the ability of the intellect to perceive independently of the imagination. It also paves the way for the use of substance in the Third Meditation (Curley 1986, 163164). The meditator concludes from this example that bodies are "perceived ... by the intellect alone" (AT VII.34; CSM II.22), not by the imagination or the senses.

The meditator focuses upon "one particular body," the piece of wax, since perceptions of bodies in general are likely to be confused (AT VII.30; CSM II.20). He notes that when the wax is placed near a fire, there are changes in the features of the wax that are perceived by the senses, but the wax still remains wax. The meditator next takes "away everything which does not belong to the wax" and discovers that extended, flexible, and changeable remain. He then asks whether flexibility and changeability are akin to changing "a square shape to a triangular shape" in the imagination (AT VII.31;

CSM II.20). However, the wax has the potential to undergo an "immeasurable number of changes," so there is a qualitative difference between changing a square into a triangle in the imagination and understanding the wax as flexible and changeable. As a result, the mediator's understanding of the wax cannot have come from the limited faculty of the imagination (AT VII.31; CSM II.21).

The meditator next wonders which perception of the nature of the wax is more perfect-that which he knew from his sensory perceptions of it with the imagination or that which resulted when he examined it closely by "tak[ing] the clothes off, as it were, and consider[ing] it naked" (AT VII.32; CSM II.22). He concludes that this closer examination is a more perfect perception of the nature of the wax. 
This denuding of the idea of the wax, the meditator declares, is done only by the intellect, and so the meditator determines that the "intellect alone" perceives bodies (AT VII.34; CSM II.22). ${ }^{10}$

Little is said in the Second Meditation about the process whereby the meditator is able to "take away everything which does not belong to the wax" (AT VII.31; CSM II.20). Marion (1999, 59-60) suggests that the simple natures in Descartes's unpublished Rules for the Direction of the Mind (c. 1628) are at play in the wax example and proposes that the material simple natures extension, shape, and movement lie behind the discovery that what remains is "extended, flexible and changeable" (AT VII.31; CSM II.20). However, pace Marion, Descartes's views change significantly between the Rules and the Meditations on two interrelated fronts, regarding (1) the method whereby we examine ideas, and (2) the status of our ideas as acquired or innate. The Meditations' skepticism about the senses is absent in the Rules. ${ }^{11}$ Regardless, when he wrote his Fourth objection, Hobbes would have had access only to the metaphor of removing clothing and Descartes's claims about the intellect's ability to "perceive."

\subsection{Hobbes's Objection: Conceiving versus Perceiving and Reasoning as the "Linking of Names"}

As previously mentioned, Hobbes misquotes the wax example by using conceive (concipere) rather than perceive (percipere): "I must therefore admit that the nature of this piece of wax is in no way revealed by my imagination, but is conceived [concipere] by the mind alone" (AT VII.177; CSM II.125). We shall see that Hobbes's usage of concipere is unsurprising given his mechanical account of the mind in the 1630 s and 1640s, in which concipere is a term of art used to describe the process by which the mind (1) represents external bodies with conceptions, and (2) inspects its conceptions to learn about the natures of the things in the world that cause those conceptions.

\footnotetext{
${ }^{10}$ Gassendi criticizes this metaphor in his Objections to the Meditations (AT VII.271-272; CSM II.189-190) and later in his Rebuttals (1644/1972, 198-199), arguing that whatever this method may be, "the bare substance ... will always retain its hidden quality" $(1644 / 1972,198)$. Similarly, Hobbes holds that we never know substance, since just as we have no idea of God, "we do not have an idea of substance" (Ninth Objection; AT VII.185; CSM II.131). ${ }^{11}$ See Garber $(1992,42)$. Curley $(1978,45)$ highlights Descartes's lack of concern with engaging the skeptic in the Rules.
} 
A prima facie reading of the Fourth Objection has Hobbes advancing two unrelated claims. The first is a claim about Descartes's failure to distinguish conceiving from imagining: "[t]here is a great difference between imagining, that is, having an idea, and conceiving in the mind, that is, using a process of reasoning to infer that something exists" (AT VII.178; CSM II.125). The second is a speculative claim about reasoning and the way the mind works that purportedly shows Hobbes's confusion about language. This claim appears to be more of a conjecture than an objection: "[W] hat shall we say if it turns out that reasoning is simply the joining together and linking of names or labels by means of the verb 'is'?" (ibid.). If this is the case, then, Hobbes claims, "inferences in our reasoning tell us nothing at all about the nature of things, but merely tell us about the labels applied to them" (ibid.).

Descartes's Reply shows that he holds this prima facie understanding of Hobbes's Fourth Objection. To the first claim, Descartes replies that he has in fact distinguished between imagining and conceiving in the wax example and also in the Sixth Meditation. To the more speculative claim, Descartes replies that Hobbes "refutes himself," and he wonders how anyone could think that reasoning is merely a linking together of names when it is so obviously a linking together "of the things signified by the names" (AT VII.178; CSM II.126). Descartes claims that it is obviously absurd to think that reasoning simply involves the linking of names, for "[w]ho doubts that a Frenchman and a German can reason about the same things, despite the fact that the words that they think of are completely different?" (AT VII.179; CSM II.126). They can reason about the same things because their ideas, though signified by different names, are about the same things in the world. Descartes thinks Hobbes holds that definitions are merely "arbitrary" and is, as a result, confused: "if [Hobbes] admits that the words signify something, why will he not allow that our reasoning deals with this something which is signified rather than merely with the words?" (ibid.). ${ }^{12}$

\footnotetext{
12 Descartes understands Hobbes, as many have, to be a definitional conventionalist. Leibniz also criticizes Hobbes as a "super-nominalist," claiming that Hobbes made definitions as well as truth depend upon human will (cf. Leibniz 1969, 128). On such a view, we can define names however we desire, irrespective of what they signify.
} 
In the next section, I argue that what Descartes treats as two unrelated claims actually reflect two interrelated arguments advanced by Hobbes. The first is an argument about the process of examining our conceptions, and the second is an argument about how the mind works - starting with the motions caused by external bodies and conceptions caused by those motions and ending with the reasoning in which we engage with the help of names. These two prima facie unrelated claims together constitute Hobbes's unified mechanical epistemology and philosophical psychology.

\section{A Mechanical Epistemology for Mechanical Minds}

\subsection{Hobbes's Philosophical Psychology: Stages 1 and 2 of the Mechanism}

Hobbes explains the mind's abilities solely in terms of bodies in motion, arguing that those who posit immaterial faculties of the mind are making mere verbal distinctions, similar to those who might claim that there was a difference between "space in the intellect and imaginary space" (spatium in intellectu et spatium imaginarium; Anti-white IV.1; Hobbes 1973, 126). In this section, I lay out the explanatory scope and power of Hobbes's view that conceptions in our minds are simply motions in the brain caused by bodies outside of us and our bodies' reaction against those motions.

The account of the mind in Elements of Law could not be more radical. Hobbes rejects all traditional distinctions between the faculties of the imagination and of the intellect, and he further avoids appealing to any inner sense such as a common sense. ${ }^{13}$ Hobbes's psychology has only two "powers of the mind": cognitive and motive. Hobbes explains the cognitive power thus:

[T]here be in our minds continually certain images or conceptions of the things without us, insomuch that if a man could be alive, and all the rest of the world annihilated, he should nevertheless retain the image thereof, and of all those things which he had before seen and perceived in it; every man by his own experience knowing that the

\footnotetext{
However, Descartes misunderstands Hobbes's emphasis on language. For Hobbes, inferences in language themselves tell us nothing about things; instead, we must examine the conceptions in the imagination that are signified by the names in the inferences. I criticize the conventionalist interpretation of Hobbes in my paper "Hobbes, Definitions, and Simplest Conceptions" (Adams forthcoming).

${ }^{13}$ See Leijenhorst (2007, 96-97, fn. 63-64) for discussion of these aspects in Leviathan and De corpore.
} 
absence or destruction of things once imagined, doth not cause the absence or destruction of the imagination itself. (EL I.8) ${ }^{14}$

Hobbes's conceptions are images caused by motions from bodies outside of us, which motions "proceed from the actions of the thing itself, whereof it is the conception" (EL I.2). These motions "reboundeth back into the nerves outward, and thence it becometh an apparition without" (EL II.9). ${ }^{15}$ In his early notes for De corpore (c. 1637), Hobbes likens the mind to a mirror: "The mind of man is a mirror capable of receiving the representation and image of all the world" (ms. 5297; Hobbes 1973, 449). ${ }^{16}$ Moreover, Hobbes uses conception as synonymous with idea-as he does later in De corpore I.3 (OL I.4).

Instead of positing separate cognitive faculties, Hobbes distinguishes sense and imagination by whether or not there is an external object presently causing the motion in the brain as well as according to the strength of the motion; there is no qualitative difference between sense and imagination. In sensing, the object is present and the motion from it is strongest (EL II.2), while in imagining, the object is absent and the motion is decayed (EL III.1). Likewise, dreams (EW III.3), mental fictions (EW III.4), and memory ${ }^{17}$ (EW III.6-7) are all explained by lingering motions that combine in diverse ways.

Hobbes also avoids any appeal to separate cognitive faculties when he explains how we know that color is not a property of bodies. Qualities such as color appear because of our body's reaction as it receives motions from bodies. In correspondence written in 1636, Hobbes explains to William Cavendish

\footnotetext{
14 This is an early version of the annihilation-of-the-world thought experiment, which reappears for a different purpose in De corpore 7 (OL I.65-66).

${ }^{15}$ Unlike in De corpore, where the heart is responsible for the outward motion in both conceptions and passions (e.g., De corpore 29.1, OL I.396), in Elements of Law the brain alone is responsible for the outward motion that forms the conception that a body is outside of us. In Elements of Law, the heart is involved only in the outward motions of the passions and "conception is nothing but motion within the head" (EL VII.1).

${ }^{16}$ Malcolm (1996, fns. 49 \& 70) dates ms. 5297 to 1642-43, but Rossi (1942) and Pacchi (1965) have suggested earlier dates. Even if these notes were written as late as 1642-43, Hobbes likely began the philosophical psychology as early as 1637: in a letter written in January of that year, Digby refers to Hobbes's work on "conceptions" in his "Logike" (Hobbes 1994, 42), and in a letter written in September of that same year, he begs Hobbes to send him any part of his "Logike" as soon as it is completed (Hobbes 1994, 50). Malcolm speculates that "Logike" refers to Ms. 5297 (Hobbes 1994, 43 fn. 2).

17 In correspondence from $21 / 31$ October 1634 , Hobbes strangely explains why one has a better memory of a friend's face than of one's own face by appealing to the remaining motions that have varying amounts of "force" (Hobbes 1994, 22).
} 
(Newcastle) that "color [is] but an effect of that motion in the brain" (Hobbes 1994, 38). Without a faculty of the intellect to judge sensations and determine their veracity, Hobbes argues that it is only through the senses themselves that we can correct deceptions such as thinking that color is a property of bodies:

And this is the great deception of sense, which also is by sense to be corrected. For as sense telleth me, when I see directly, that the colour seemeth to be in the object; so also sense telleth me, when I see by reflection, that colour is not in the object. (EL II.10)

We are deceived if we take color to be a property of bodies, but when we attend to our experience of things such as mirrors, we are able to see our error. Hobbes's strange argument from seeing a reflection in a mirror goes as follows. An image in a mirror appears to be blue, but we know that "the image of any thing seen by reflection ... is not any thing in or behind the glass" (EL II.6). Since a mirror is blue at one moment and not at another, we infer by attending to this sensory experience that blue is not in the mirror, that is, being blue is not part of the mirror's nature. Hobbes thinks this is so clear that "every man may prove [it] to himself" (EL II.6).

This argument would have been unconvincing to anyone who held that vision occurs by means of species propagated through media. Indeed, Hobbes articulates a simplified version of the species view as his target: "the introduction of species visible and intelligible ... passing to and fro from the object, is worse than any paradox, ... [it is] a plain impossibility" (EL II.4). Hobbes's assertion that anyone who encounters a mirror will understand that color is obviously not a property of objects clearly does not establish the impossibility of the species view; neither do his other arguments in Elements of Law. Rather, we should understand Hobbes as showing the explanatory scope of the mechanical mind hypothesis insofar as it can account for such visual phenomena without any appeal to entities such as species that were, in Hobbes's view, not mechanically intelligible. 
Anti-White XXVII.19 (1642-43) provides support for understanding this to be Hobbes's strategy.

There he emphasizes all that can be explained without any recourse to an incorporeal mover, in this case, the soul:

[E]very perception is a motion in the parts of an animal's body; these, though they are called 'animal spirits' and 'vital spirits', are nevertheless [themselves] bodies; and the motion is aroused by objects, which are also bodies. So up to now we need to have no recourse to an incorporeal mover. (Hobbes 1973, 326; Hobbes 1976, 331) 18 $^{18}$

Hobbes later repeats this final phrase in Anti-White XXVII, when showing that he can also explain the presence and lingering of conceptions without appeal to an incorporeal mover. Furthermore, as in Elements of Law, Hobbes holds in Anti-White that animal motion and the intention to accomplish a goal can also be explained with such a mechanical explanation, without needing to appeal to anything incorporeal (Hobbes 1976, 332). Although undoubtedly unsatisfying to those holding the species view, Hobbes viewed the strength of his mechanical hypothesis of the mind as the scope of the phenomena it could explain.

\subsection{From the Mechanical Mind to Mechanical Epistemology: Stages 3 and 5 of the Mechanism}

\subsubsection{Conceptions and Language}

Some commentators have focused on Hobbes's nominalism. ${ }^{19}$ Hobbes is interested in names in his writings from the 1640 s onward; indeed, in Elements of Law he claims that only names are universal and that universals are found nowhere in nature (EL V.5-6), a view he also endorses in Anti-White II.6 (1973, 112). However, names play a more limited role for Hobbes than is generally recognized. In the Elements of Law and later works such as De corpore, both private marks and public names function merely as devices to help us remember the connections we discover among our conceptions when adding and

\footnotetext{
18 There is also a similar account in Tractatus Opticus I (1644).

${ }^{19}$ For example, Hungerland and Vick (1973; in Hobbes 1981); Jong (1986, 1990); Machamer and Sakellariadis (1989); and Pettit (2008).
} 
subtracting them in the act of conceiving. ${ }^{20}$ In this section, I distinguish this limited role of language from the essential role conceptions play in scientific knowledge.

Hobbes distinguishes between two kinds of knowledge in Elements of Law: knowledge of sense and scientific knowledge. Both come from experience: knowledge of sense is due to the experiences brought about by objects outside of us, while scientific knowledge arises from "experience men have of proper use of names in language" (EL VI.1). Hobbes further characterizes scientific knowledge as the "knowledge of the truth of propositions" (EW VI.1). Thus far, his epistemology seems wholly dependent upon language, and scientific knowledge seems characterized only by individuals' knowledge of how names are joined in propositions. This prima facie way of understanding scientific knowledge is identical to how Descartes understood Hobbes's Fourth Objection, as already discussed.

However, as we shall see, Hobbes's analysis shows that scientific knowledge is more than merely knowing how to use names. Marks and names are important only as the means by which we engage in reasoning; they are the means by which we organize our "remembrances" (EL VI.1). Indeed, Hobbes allows for a personal mark to be any sensible object, such as a rock left in a certain place to warn of an upcoming danger at sea (EL V.1), and not merely a verbal mark or name. Indeed, instead of words, humans could have used different colored rocks as personal marks and then also as public names.

Furthermore, there is no language of thought for Hobbes. Instead, the orderly succession of conceptions, not names or marks, constitutes the "discourse of the mind" (EL IV.1). In Anti-White, Hobbes rejects Thomas White's view that words "reflect the mind":

"Words," he says on his page 32, "reflect the mind." (We note, by the way, that this is utterly ridiculous, for what resemblance can there be, pray, between a word and the mind? And how is it that, if "words reflect the mind," the languages of all nations are not alike, as their minds are?) (Hobbes 1973, 126; Hobbes 1976, 53)

\footnotetext{
${ }^{20}$ See EL V.1. I argue that this is the case in later works, such as De corpore, in my paper "Hobbes on Maker's Knowledge and Scientia."
} 
Here Hobbes rejects the very view of language and the mind, already discussed, that Descartes thrusts upon him in the Replies when Descartes wonders "[w]ho doubts that a Frenchman and a German can reason about the same things, despite the fact that the words that they think of are completely different?" (AT VII.179; CSM II.126). From Hobbes's earliest work in the 1640s, then, conceptions are the vehicles of the mind, and the names that signify conceptions are our vehicles of convenience for use in reasoning.

Hobbes introduces truth and evidence to clarify scientific knowledge. Scientific knowledge is "evidence of truth, from some beginning or principle of sense" (EL VI.4). Truth is a property of propositions, and the truth of a proposition depends upon whether, in the case of an affirmative proposition, the name in the predicate "comprehendeth" the name in the subject (EL V.10). ${ }^{21}$ The truth of the proposition "charity is a virtue" (Hobbes's example) thus depends upon whether the name virtue comprehends the name charity. ${ }^{22}$ Since it does, the proposition is true.

Evidence provides a reason to believe that the conclusion of a syllogism is true. Evidence is about the relationship of a name to a conception:

[Evidence] is the concomitance of a man's conception with the words that signify such conception in the act of ratiocination. For when a man reasoneth with his lips only, to which the mind suggesteth only the beginning, and followeth not the words of his mouth with the conceptions of his mind ... though he begin his ratiocination with true propositions, and proceed with perfect syllogisms, and thereby make always true conclusions; yet are not his conclusions evident to him, for want of the concomitance of conception with his words. For if the words alone were sufficient, a parrot might be taught as well to know a truth, as to speak it. (EL VI.3)

Examining one's conceptions to be sure that the words used in reasoning signify those conceptions is what distinguishes scientific knowledge from mere knowledge of sense (EL VI.4). Such examination

\footnotetext{
${ }^{21}$ Hobbes understands one name comprehending another to be a containment relation. In the Elements of Logick, Du Moulin connects mathematical containment with relations between subjects and attributes in logic: "that which in the Mathematicks is said, to containe, in Logick is said, to be attributed" $(1624,122)$, and he illustrates this logical relationship by appeal to relationships among numbers, such as that "[t]welve containeth six, and six containeth three, therefore twelve containeth three" $(1624,124)$. Hobbes uses a nearly identical example in De corpore 7.9 (OL I.86-87) to talk about how larger numbers are compounded (componere) out of smaller ones. ${ }^{22}$ In the discussion that follows, I italicize names and render conceptions in capitals.
} 
provides evidence that the conclusions of syllogisms are actually true and not accidentally so-the latter being what Hobbes describes in the case of the individual who reasons perfectly well but whose conclusions, like those of a parrot, "are not... evident to him." A parrot can "speak" a true conclusion, but this will be accidental.

We discover that one conception comprehends another conception-and thus gain evidenceby finding a genus-species relationship: the genus conception comprehends the species conception. How do we discover this genus-species relationship when only imagistic conceptions are in the mind? We do so by first discovering which more general conceptions constitute a particular conception when they are compounded together (componere). We do this by calling to mind the image available and then seeing which more general conceptions always co-occur when we inspect that particular conception and resolve (resolvere) it into these general conceptions. In later works such as De corpore, Hobbes refers to these two activities of resolving and compounding as analysis and synthesis (OL I.61-62) and also as subtracting and adding (OL I.3).

We find these two cognitive activities in the early notes for De corpore (c. 1637), where Hobbes claims that the individual left behind after the annihilation of the world would "subtract and compound" conceptions (Hobbes 1973, 449). In De corpore 6.2, when we consider the conception MAN, we discover through analysis and synthesis that MAN is "compounded" from the genus conceptions FIGURATE, ANIMATE, and RATIONAL (OL I.59-60), because whenever we resolve MAN through analysis, these genus conceptions arise. We then reconstruct MAN back together in synthesis in our mind. Hobbes's process of mental compounding or adding together is simplistic, something like FIGURATE + ANIMATE + RATIONAL $=$ MAN. Knowing that ANIMATE is part of MAN confirms that the genus conception ANIMATE comprehends MAN and provides evidence of the truth of "man is animate." If one discovers that a name used in a proposition does not signify a conception (e.g., an absurdity like incorporeal substance), then one knows that that proposition cannot be true. 
Names also help us remember necessary connections among conceptions, or what Hobbes refers to as the "necessary coherence" of conceptions. He argues that "the invention of names hath been necessary for the drawing of men out of ignorance, by calling to their remembrance the necessary coherence of one conception to another" (EL V.13). By "necessary coherence," Hobbes does not mean the association of conceptions with one another through constant accidental occurrence. For example, with a limited set of experiences, the conception RED HAIR might become associated with the conception MAN. For Hobbes, this type of association would not be necessary, since we can readily find instances of MAN without instances of RED HAIR. Instead, Hobbes's reference to necessary coherence means that we discover that there are containment relationships among our conceptions, which we then signify by using names in propositions.

\subsubsection{The Activity of Philosophizing}

Beyond the role that conceptions have in providing evidence, the subject matter of philosophy itself also consists of conceptions and only indirectly things in the world. Indeed, in the early notes for De corpore (c. 1637), we find that when we reason "we compute nothing but our phantasms or ideas" (Hobbes 1973, 450; cf. OL I.82). In Anti-White XXVII.1, Hobbes argues that philosophy should concern only those things that are conceivable, or imaginable (imaginabile), so we will not even offer definitions for things that we cannot imagine, such as incorporeal substance (Hobbes 1973, 312). Because philosophy deals only with things that are imaginable, such as animals and trees, it follows that things of which we cannot have a conception, such as God or angels, are excluded from philosophy.

Given the constraint of conceivability, philosophizing involves examining conceptions in order to learn the natures of the bodies in the world that cause those conceptions. As a result, Hobbes's first philosophy ignores many traditional metaphysical topics, such as the existence and eternality of the soul 
or the existence of God, since these fall outside of the conceivable. ${ }^{23}$ Instead, Hobbesian first philosophy seeks to "understand the beginning of the teaching of nature" (OL I.81) and thus inaugurate a first philosophy that will be useful for the natural philosopher. ${ }^{24}$

We discover a thing's nature by the same mental activity we employ when determining whether a given name comprehends another name. The only difference between the two activities is the extent of the analysis that is undergone-how far we descend, as it were, into the conceptual bedrock. As already discussed, to determine whether a given conception comprehends another conception, we must analyze the latter conception in order to determine whether, when it is compounded back together from genus conceptions, it is constituted by the former conception along with others.

However, to determine a thing's nature we must continue this analysis further until we arrive at the most basic mental constituents out of which all conceptions are composed-what Hobbes calls the "simplest conceptions"-BODY, SPACE, and MOTION. Then we must compound these back together through synthesis to build the original conception out of the simplest conceptions we have discovered. This more involved role for conceptions-in analysis from a complex conception to simplest conceptions and back to the original conception through compounding in synthesis-can be found in nascent form in Anti-White and in manuscript notes for De corpore. My discussion of this role of conceptions is based on

\footnotetext{
${ }^{23}$ In his Fifth Objection, Hobbes argues that Christians are forbidden from making graven images because "otherwise we might think that we were conceiving of him who is incapable of being conceived" (AT VII.180; CSM II.127). Regarding this passage, Martinich $(2002,54)$ appeals to Leviathan 11 (EW III.92-93) to argue that "[t]he clear thrust of this passage [from Leviathan] is that people can conceive of God even if they have no sense experience of him." However, Martinich's claim results from a failure to see that Hobbes uses conceive in two distinct ways: first, to discuss the process of forming conceptions, and second, to refer to the process of analyzing and synthesizing in order to learn about a thing's nature or whether it exists (for examples of the first usage, see EL I.8, EL III.4, OL I.3-4, and OL I.21; for examples of the second usage, see EL XI.2, OL I.9, and OL I.68). For Hobbes, we can conceive only that there is a God-the second sense of conceive-when we look at the world around us and conceive that there is a cause of all that is. Duncan highlights that even though Hobbes does not think that we can have an idea of God, Hobbes is nevertheless committed to the existence of immaterial beings, such as angels, in his Objections to the Meditations $(2005,444)$.

${ }^{24}$ In Anti-White, the imaginability restriction allows Hobbes to redefine radically being (ens) as "everything that has space, or which can be measured as to length, breadth and depth" (Hobbes 1976, 311), so that ens and "body" become synonymous.
} 
the mature account in the published version of De corpore (1655), with reference to the earlier works throughout.

Hobbes argues in De corpore 6.4 that the method (methodus) used to achieve knowledge of the causes of singular things first requires analysis from the conception of a singular thing down to simplest conceptions and then synthesis from those simplest conceptions back to the conception of that thing (OL I.61). As the following examples illustrate, Hobbes believes that by this method of analysis and synthesis we can know the causes or natures of all singular things.

Hobbes provides two examples in De corpore 6.4 of how the analysis/synthesis movement works. The first is of the conception SQUARE:

[L]et any conception or idea of a singular thing be proposed, say a square. The square is resolved [resolvetur] into: plane, bounded by a certain number of lines equal to each other, and right angles. Therefore we have these universals or components of every material thing: line, plane (in which a surface is contained), being bounded, angle, rectitude, and equality. If anyone finds the causes or origin of these, he will put them together [componet] as the cause [causam] of the square. (Hobbes 1981, 293; OL I.61)

The conceptions into which Hobbes resolves SQUARE are geometric conceptions, and the way to find "the causes or origin of these" will require further analysis until one reaches simplest conceptions. For Hobbes, basic definitions in geometry are "explications of our simplest conceptions" (conceptuum nostrorum simplicissimorum; Hobbes 1981, 295; OL I.62). Take the conception LINE from the example. Hobbes defines LINE as follows: "a line is made by the motion of a point" (linea fiat ex motu puncti; OL I.63). When we have resolved LINE into the parts of its definition, we have then arrived at simplest conceptions: BODY (point), MOTION, and SPACE. To learn the cause of SQUARE we compound (componere) these back together.

Hobbes's second example is GOLD. We resolve GOLD into the conceptions SOLID, VISIBLE, and HEAVY (OL I.61). These conceptions will have to be resolved further until we reach simplest conceptions. The conception SOLID (solidum) is a geometric conception, and it is caused by the motion of SURFACE (superficies) (OL V.153). SURFACE resolves into LINE and MOTION, and after further resolution we reach 
the simplest conceptions BODY, SPACE, and MOTION. However, the conceptions VISIBLE and HEAVY are not geometric conceptions. Since Hobbes claims that "the causes [causae] of all single things are known" (Hobbes 1981, 293; OL I.292) by analysis and synthesis, we should expect to know the causes of VISIBLE and HEAVY as well, but in the next section I question whether Hobbes can claim this about the nongeometric natures of things, such as that the nature of GOLD is to be VISIBLE. ${ }^{25}$ Thus, we shall see that in the case of the wax, Hobbes can hold only that we know that its nature is geometric.

\subsubsection{Questioning an Epistemology of Simplest Conceptions}

Several questions arise about Hobbes's account of how we have scientific knowledge (scientia) of things' natures by analyzing particular conceptions of them down to simplest conceptions and then putting them back together in synthesis. How can we have universal knowledge when we have only images of particular bodies at our disposal? While criticizing Thomas White's definition of place in Anti-

White IV.2, Hobbes explains what conceptions represent:

He [White] ought to have said that [i] the imaginary surface caused by the sight of the running water was an image of the water, not as water, but as body [corporis], and that [ii] the image therefore represents [repraesentare] not that particular water but any water, or air, or body of the same size and shape (Hobbes 1973, 126; Hobbes 1976, 53).

Here Hobbes is concerned with what is represented in the imagination by the conception we have of moving water. The generality of what Hobbes thinks conceptions represent conflicts with his later view that there no universal conceptions (cf. De corpore 2.9; OL I.17-18). One way to resolve this conflict is to hold that the only universal knowledge represented by our conceptions is geometrical. Indeed, simplest conceptions for Hobbes are all geometric, such as SPACE - so we can have universal knowledge of geometry because each particular conception represents geometric universals.

\footnotetext{
${ }^{25}$ Hobbes provides a third example in De corpore 6.3 (OL I.60) that I do not discuss.
} 
Hobbes's account of representation in Anti-White relies upon the view that there are various conceptions we may have for a bit of water. ${ }^{26}$ For example, upon seeing a bit of water and having a conception WATER arise, we may consider the water as something that we can rely upon for quenching thirst, and an analysis of that particular conception may therefore result in the genus conceptions WET, TRANSPARENT, POTABLE, and STILL. When considering that same conception WATER as a surface, the conception WATER would represent BODY generally: not any particular body or bit of water, but "any water, or air, or body of the same size and shape" (Anti-White IV.2; Hobbes 1973, 126; Hobbes 1976, 53). As we have seen, we arrive at the conception SURFACE by analyzing the conception WATER and then by continued analysis arrive at the simplest conceptions BODY, MOTION, and SPACE. After putting the conception WATER back together in our mind from these constituent parts, we would know the (geometric) nature of WATER. This synthesis would begin with the most basic form of body, a point, and then consider it in motion. This motion of the point would form a line, and adding motion to that line would form a surface.

Perhaps Hobbes is entitled to hold that any particular conception represents geometric universals, but what is the status of nongeometric genus conceptions reached in analysis, such as WET or POTABLE? How can we know from analysis whether the nature of WATER is to be POTABLE? As already discussed with the gold example, Hobbes claims that through analysis and synthesis we can know "the causes [causae] of all single things" (OL I.292), but how can we know that these are the causes of WATER (its nature is made up by its causes) when our conception WATER is only an image of a particular bit of water encountered in experience? Given the paucity of furniture in Hobbes's mechanical mind, Hobbes cannot hold that we know that the nature of WATER is to be POTABLE, or that the nature of GOLD is to be VISIBLE. We can examine imagistic conceptions and learn about general geometric properties from them, but we cannot know that the nongeometrical properties we discover in analysis

\footnotetext{
${ }^{26}$ Hobbes claims this in Elements of Law: "Seeing there be many conceptions of one and the same thing, and for every several conception we give it a several name." (EL V.5).
} 
are part of that thing's nature. The natures we can know from having examined only a single imagistic conception of single bit of that thing are geometrical, and this is due to our imagistic conceptions representing universal geometric (spatial) properties. Once we discover these universal geometric properties, we name them so that we can remember them.

Nongeometric genus conceptions arrived at by analysis, such as WET or POTABLE, are accidents that are "not common to all bodies" (De corpore 8.3; OL 1.93), and as such, they are present at some times but not at others. Water will be water whether potable or not. Indeed, discovering whether some property is part of a thing's nature or is, like color, merely due to our bodies' interaction with it, is a substantial part of Hobbesian natural philosophy. This "decision" about the properties of bodies, Hobbes argues, "is not so easy in physics, where the concern is with the causes of sensible phantasms, which present themselves as the very things of which they are the phantasms and deceive many" (Hobbes 1981, 303; OL I.66). The conception we have of WATER appears to be such that POTABLE may seem to be part of the nature of water upon analysis. So we must discover "whether a phantasm is [from] matter, or some natural body, or whether it is some accident of a body" (Hobbes 1981, 305; OL I.67). We determine whether a phantasm is from an external body or merely an accident of a body (such as our body) by comparing a given idea, say a conception from a single experience of water, with "the properties of matter and accident, which we have already discovered from their definitions by the synthetic method" (Hobbes 1981, 305; OL I.67). When we compare these two ideas, we must see whether the properties in question can be taken away in our mind: "[W]hereas the idea arises, is destroyed, is increased, is diminished, and is moved at our decision, it is certain that it [the phantasm] is not matter but accident" (Hobbes 1981, 305; OL I.67). After we have analyzed WATER, we discover which properties of WATER are part of its nature by doing exactly this comparison. We learn that we can remove or "destroy" POTABLE from WATER, but we cannot remove its geometric properties and have it still be WATER. It would not be WATER if it were not partly composed by SURFACE, but WATER can be 
considered as IMPOTABLE and still be WATER. This entire procedure-analysis, synthesis, and comparison of conceptions-is, as I argue in the next section, crucial for understanding Hobbes's Fourth Objection to the Meditations. Indeed, we know the nature of the wax by doing what Hobbes says in De corpore 6.8 , and we can know only that nature of the wax is geometrical.

Finally, why does Hobbes think that we have scientific knowledge of a thing's nature only when we analyze from the particular conception to simplest conceptions and then compound from simplest conceptions through synthesis? What is it about the activity of engaging in analysis and synthesis that provides scientia? I suggest that for Hobbes, scientific knowledge is possible only on this model because it is mechanically intelligible; Hobbes's method for scientific knowledge is trustworthy because each step in the method has been made mechanically intelligible in terms of bodies in motion. So humans have scientific knowledge only with the full engagement of this mechanism, and it is in this sense that Hobbes provides a mechanical epistemology.

I have discussed each of the elements of the scientific knowledge mechanism with the exception of stage 4-that the human cognitive power "apprehends" the simplest conceptions reached after analysis. Hobbes emphasizes the importance of the entire mechanism for the possession of scientific knowledge, and we shall see in the next section that this is the key point of difference between Hobbes and Descartes in the Fourth Objection and Descartes's Reply. Regarding stage 4, our apprehension of the simplest conceptions BODY, MOTION, and SPACE is not in itself scientific knowledge. Instead, our apprehension of simplest conceptions has the same epistemic status as sensory experience; whereas we have scientia when we apply analysis and synthesis to a particular conception, we have only cognitio of simplest conceptions considered in isolation. ${ }^{27} \mathrm{I}$ emphasize this aspect of stage 4 as further support for

\footnotetext{
${ }^{27}$ See De corpore 6.4 (OL I.61). Hobbes uses cognoscere to describe apprehension of simplest conceptions and contrasts it with scire to describe knowledge of the "causes of things" acquired by analysis and synthesis. The Molesworth translation (EW I.68) and the most recent translation of Part I of De corpore (Hobbes 1981, 292-293) obscure this distinction between cognoscere and scire by translating both as "know/known".
} 
my claim that for Hobbes, scientific knowledge is acquired only by the engagement of this entire mechanism. Merely apprehending simplest conceptions would be insufficient.

\section{Revisiting Hobbes's Fourth Objection to the Meditations}

Descartes's quick dismissal of Hobbes's Fourth Objection shows that he misunderstands Hobbes's terse objections. In their 1641 exchange, Descartes takes the Fourth Objection to consist of two unrelated and poorly defended claims, as already noted: first, a claim that Descartes fails to distinguish conceiving from imagining; and second, a speculative claim about reasoning and the way the mind works that shows Hobbes's confusion about language. However, if we consider these two claims in light of the mechanical epistemology and philosophical psychology Hobbes develops in his other work, we can see not only that the two claims are related to each other, but also that taken together, they constitute Hobbes's strongest objection to the Cartesian view of scientific knowledge and the mind. Hobbes should certainly have articulated and defended these claims better, but given the broad range of Hobbes's works at our disposal, we must reject Descartes's dim view of Hobbes's Fourth Objection.

Hobbes's claim that Descartes fails to distinguish between conceiving and imagination should be understood in light of Hobbes's account of the activity of the mind as conceiving. As we have seen, Hobbes uses conceiving to describe both the formation of conceptions by the mind and the cognitive power's inspection of those conceptions to learn about the nature of the things in the world that cause them. The following comment from Hobbes's Fourth Objection, which Descartes completely ignores in his Reply, now makes sense: "Even the Peripatetics of classical times taught clearly enough that a substance is not perceived by the senses but is inferred by reasoning" (AT VII.178, CSM II.125). Descartes obviously does not think that the wax's nature is "perceived by the senses," but we should understand Hobbes's point to be that it is an illegitimate short-cut-the postulation of an uninformative black boxwhen Descartes posits the existence of the intellect and describes its activity by saying that it "perceives" the nature of the wax. 
Hobbesian scientific knowledge of a thing's nature requires that, rather than relying on a posited intellect, a correct process of reasoning must be undertaken. So when Hobbes claims that Descartes "has not explained how they [imagining and conceiving] differ," he means that Descartes has drawn a distinction in name only, without providing any of the entities or activities that make up the mechanism of conceiving. For Hobbes, positing the existence of an intellect and claiming that it "perceives" the natures of things is no better than saying that we simply perceive the natures of things by our senses. By providing a mechanism, Hobbes shows how scientific knowledge is mechanically intelligible, something for which the intellect posited by Descartes is too impoverished.

Furthermore, we now see the shortcomings of Descartes's Reply to Hobbes's Fourth Objection. When Hobbes says "inferences in our reasoning tell us nothing at all about the nature of things, but merely tell us about the labels applied to them" (AT VII.178; CSM II.125), he means that simply examining our inferences in language is worthless. Names are merely tools of convenience that we use to remember what we have discovered through analysis and synthesis. Names by themselves tell us nothing about things in the world. To know a thing's nature, we must inspect the conceptions to which our names refer and then engage in analysis and synthesis.

It would be correct to view Hobbes's second claim in the Fourth Objection as merely speculative if we did not have the full mechanism in his other works. It is understandable that Descartes finds the claim farfetched and thinks that absurdity follows from what he takes to be Hobbes' argument: "[W]hen he concludes that the mind is a motion he might as well conclude that the earth is the sky, or anything else he likes" (AT VII.179; CSM II.126). But what appears to be a speculative account in Hobbes's Fourth Objection is a brief summary of the main points of the complete mechanism that Hobbes develops in his work from the late 1630 s and early 1640 s, coming to completion in De corpore. The connection of the mind to the outside world in terms of motions produced by external bodies is missing from the mechanism summary in Hobbes' Fourth Objection, but as we have seen, it figures prominently in his 
other work. While we may excuse Descartes for his flippant rejection of what appears to be a speculative conjecture, the broader context shows that Hobbes is in fact criticizing Descartes's faculty psychology and epistemology as unintelligible to mechanical philosophy.

\section{Conclusion}

In this paper, I have argued that we must examine the 1641 exchange between Hobbes and Descartes within the broader context of Hobbes's work in the late 1630 s and early 1640 s and the fruition of that work in De corpore. Descartes's curt Replies to Hobbes are understandable, but to appreciate what Hobbes says in the brief Objections, we must consider Hobbes's general project at the time by taking his other work into account. I have argued that we must understand Hobbes's Fourth Objection as part of his broader program, both his rejection of the traditional faculty psychology that Descartes accepts and his endeavor to develop a mechanical epistemology and philosophical psychology that will together provide a mechanism for scientific knowledge and make it mechanically intelligible.

\section{References}

Adams, M.P. Forthcoming. "Hobbes, Definitions, and Simplest Conceptions," Hobbes Studies.

Adams, M.P. Manuscript. "Hobbes on Maker's Knowledge and Scientia."

Alanen, L. 2003. Descartes's Concept of Mind. Cambridge, MA: Harvard University Press.

Clarke, D. 2003. Descartes's Theory of Mind. Oxford: Clarendon Press.

Costa, M. J. 1983. "What Cartesian Ideas are Not." Journal of the History of Philosophy 21.4: 537-549.

Curley, E. M. 1978. Descartes against the Skeptics. Cambridge: Harvard University Press.

Curley, E. M. 1986. "Analysis in the Meditations: The Quest for Clear and Distinct Ideas." In A. O. Rorty, ed., Essays on Descartes' Meditations, Berkeley: University of California Press, 153-176.

Curley, E. M. 1995. “Hobbes versus Descartes." In R. Ariew and M. Grene, eds., Descartes and His Contemporaries, Chicago: University of Chicago Press, 97-109.

Descartes, R. 1964-. Oeuvres de Descartes. Adam and Tannery, eds. Paris: J. Vrin.

Descartes, R. 1985. The Philosophical Writings of Descartes, Vols. 1 and 2, J. Cottingham, R. Stoothof, and D. Murdoch, trans. Cambridge, MA: Cambridge University Press.

Descartes, R. 1991. The Philosophical Writings of Descartes. Vol. 3, The Correspondence, J. Cottingham, R. Stoothof, D. Murdoch, and A. Kenny, trans. Cambridge, MA: Cambridge University Press.

Duncan, S. 2005. "Hobbes's Materialism in the Early 1640s." British Journal for the History of Philosophy 13.3: 437448.

Du Moulin, P. 1624. The Elements of Logick. N. De-lavvne, trans. London: Royal Exchange.

Garber, D. 1992. Descartes' Metaphysical Physics. Chicago: University of Chicago Press.

Gassendi, P. 1644/1972. The Rebuttals against Descartes. In Selected Works of Pierre Gassendi, C. Bush, ed. and trans. New York: Johnson Reprint Co.

Hobbes, T. 1839-45. Thomae Hobbes Malmesburiensis Opera Philosophica. 5 vols. G. Molesworth, ed. London: John Bohn. [cited as OL] 
Hobbes, T. 1928 [ms. c. 1640, published 1650]. The Elements of Law, F. Tönnies, ed. Cambridge: Cambridge University Press.

Hobbes, T. 1973 [1642-43]. Critique du de Mundo de Thomas White, J. Jacquot and H.W. Jones, eds. Paris: Vrin. Hobbes, T. 1976 [1642-43]. Thomas White's De Mundo Examined, H. W. Jones, trans. London: Bedford University. Hobbes, T. 1981. Computatio sive Logica: Logic. A. P. Martinich, trans. and commentary, and I.C. Hungerland and G. R. Vick, eds. New York: Abaris Books.

Hobbes, T. 1994. The Correspondence of Thomas Hobbes, 2 vols., N. Malcolm, ed. Oxford: Clarendon.

Hobbes, T. 2005. The English Works of Thomas Hobbes. Facsimile of 1839 G. Molesworth edition, Elibron Classics. New York: Adament Media. [cited as EW]

Hungerland, I. C. and G. R. Vick. 1973. "Hobbes's Theory of Signification." Journal of the History of Philosophy 11: 459-482.

Jong, W. R. de. 1986. “Hobbes's Logic: Language and Scientific Method.” History and Philosophy of Logic 7: 123142.

Jong, W. R. de. 1990. “Did Hobbes have a Semantic Theory of Truth?” Journal of the History of Philosophy 28: 6388.

Leibniz, G. W. 1969. G.W. Leibniz Philosophy Papers and Letters, L. E. Loemaker, ed. and trans. Dordrecht: Reidel. Leijenhorst, C. 2001. The Mechanisation of Aristotelianism. Leiden: Brill.

Leijenhorst, C. 2007. "Sense and Nonsense about Sense: Hobbes and the Aristotelians on Sense Perception and Imagination." In P. Springborg, ed., The Cambridge Companion to the Leviathan. Cambridge: Cambridge University Press, 82-109.

Lennon, T.M. 1974. "The Inherence Pattern and Descartes' Ideas." Journal of the History of Philosophy 12.1: $43-52$.

Machamer, P. K. and S. Sakellariadis. 1989. "The Unity of Hobbes's Philosophy." In T. Airaksinen and M. A. Bertman, eds., Hobbes: War among Nations. Aldershot: Gower Publishing, 15-34.

Machamer, P. and J. E. McGuire. 2009. Descartes's Changing Mind. Princeton: Princeton University Press.

Machamer, P. and M. P. Adams. Forthcoming. "Descartes on Intuition and Ideas," In L. Osbeck and B. Held, eds., Rational Intuition: Philosophical Roots, Scientific Investigations. Cambridge: Cambridge University Press.

Malcolm, N. 1996. "A Summary Biography of Hobbes." In T. Sorell, ed., The Cambridge Companion to Hobbes. Cambridge: Cambridge University Press.

Marion, J.-L. 1999. Cartesian Questions. Chicago: University of Chicago Press.

Martinich, A. P. 2002. The Two Gods of the Leviathan. Cambridge: Cambridge University Press.

Mori, G. 2012. “Hobbes, Descartes, and Ideas: A Secret Debate." Journal of the History of Philosophy 50: $197-212$.

Pacchi, A. 1965. Convenzione e ipotesi nella formazione della filosophia naturale di Thomas Hobbes. Firenze.

Pettit, P. 2008. Made with Words: Hobbes on Language, Mind, and Politics. Princeton: Princeton University Press.

Raylor, T. 2001. "Hobbes, Payne, and 'A Short Tract on First Principles." Historical Journal 44.1: 29-58.

Rossi, M. M. 1942. Alle fonti del deismo e del materialismo moderno. Firenze.

Shapiro, A. 1973. "Kinematic Optics: A Study of the Wave Theory of Light in the Seventeenth Century." Archive for the History of the Exact Sciences 11: 134-266.

Sorell, T. 1995. "Hobbes's Objections and Hobbes's System." In R. Ariew and M. Grene, eds., Descartes and His Contemporaries. Chicago: University of Chicago Press, 83-96.

Tuck, R. 1988. "Hobbes and Descartes." In G.A.J. Rogers and A. Ryan, eds., Perspectives on Thomas Hobbes. Oxford: Clarendon, 11-41.

Wagner, S. I. 1995. “Descartes' Wax: Discovering the Nature of the Mind." History of Philosophy Quarterly 12: 165183.

Zagorin, P. 1993. “Hobbes's Early Philosophical Development.” Journal of the History of Ideas 54.3: 505-518. 